\title{
Negative Happiness
}

\section{Adam Barkman}

I

$\mathrm{n}$ this paper, I will compare the philosophies of the Buddha and Epicurus. Unusual? Yes. But my intention herein is not a general comparison; rather, I want to explore to what extent these two men accepted what I call "negative happiness." What is negative, and by extension, positive, happiness? I think we can prepare ourselves for this distinction with two analogous distinctions: (1) the distinction between positive and negative freedom, wherein positive freedom sees true freedom as internal control over oneself, while negative freedom sees true freedom as the lack of external coercion, and (2) the distinction between charity and unselfishness, wherein charity stresses selfdenial, though not as an end in itself, whereas unselfishness emphasizes not primarily doing good things for others but rather going without them ourselves. ${ }^{1}$ Thus, in regard to positive and negative happiness, we can say that while positive happiness sees true happiness as a substantial good that makes virtue a constituent of happiness and regards happiness as something more than the avoidance of suffering, negative happiness sees true happiness as simply the absence of suffering.

Consequently in this paper, I want to argue, firstly, that both the Buddha and Epicurus subscribed to negative happiness; and, secondly, that negative happiness as such is a valuable but ultimately incomplete understanding of true happiness.

\section{The Negative Happiness of the Buddha}

Siddhārta Gotama (563-483 BC), the man who would later be known as "the Buddha" or "the Enlightened One," was once the prince of a kingdom in northern India (today, Nepal). As the legend goes, there was a prophecy that Siddhārta would become either the spiritual saviour of the world or a "wheel-turning king," who is a long-living, earthly king who rules in power and righteousness. For whatever reason, Siddhārta's father, the ruling king at the time, wanted Siddhārta to become a wheel-turning king and so he sought to keep his son focused on the pleasures associated with kingship and earthly power. However, the king's effort was of no avail, for Siddhārta received Four Signs, which opened his eyes to the fact of old age, sickness, death and, most importantly, to the possibility of escaping from these three, all of which, for

${ }^{1}$ C. S. Lewis, "The Weight of Glory," in C. S. Lewis: Essay Collection and Other Short Pieces (London: HarperCollins, 2000), 96. 
him, ultimately came to represent dubkha or suffering. And so seeing that suffering threatened to extinguish all earthly pleasures, the Buddha left behind his family and kingdom to seek the means to escape from suffering.

For the next six years, Siddhārta studied and trained with many Indian philosophers and yogis, seeking a means to eliminate suffering permanently; however, the best these philosophers and yogis could do was temporarily suspend suffering, not obliterate it all together. Indeed, some of these yogisthe more ascetic of the group-even seemed to increase suffering via selfmortification; such extreme measures, Siddhārta decided, were not the way to end suffering, and so he left his teachers behind; nevertheless, Siddhārta did not leave empty-handed, for, setting aside the very real possibility that Buddhism acquired the idea of a world saviour from Zoroastrianism (which had made inroads into northern India), ${ }^{2}$ Siddhārta accepted the Hindu doctrines of karma ("fruits of action"), samsara ("the wheel of rebirth") and most importantly, the idea that escape from samsära and suffering is the highest good. Indeed, when Siddhārta ultimately achieved enlightenment and became the Buddha, he spoke of his own enlightenment as simply the inverse of Hindu enlightenment; that is, while the Hindus spoke of enlightenment as the realization and experience of the self as atman, which is Brabman or the totality of all substantial things, the Buddha spoke of enlightenment first as the realization of anatman, which means "no self" or the denial of any substantial reality, and second as the subsequent experience of the extinguishing-of-self or nirvana through such knowledge. All of these points became explicit in the Buddha's first sermon on the Four Noble Truths, ${ }^{3}$ which I believe will clearly show the Buddha to have been a proponent of negative happiness.

The First Noble Truth begins by acknowledging that life is suffering. Combining this most fundamental and primary truth with the fact that the Buddha denied the existence of all substances or things which endure unchanging throughout time-indeed, going so far as to see everything as a interpenetrating, co-dependent world of flux-it is clear that the Buddha saw life-any and all life, even the life in the aruppa or the highest, formless realms of existence ${ }^{4}$ - as fundamentally connected with pain, falsehood and chaos (since life follows no absolute or substantial order, not even the apparently unsubstantial law of karma). It should be added that while pain is the necessary cause of suffering, pain is not identical with suffering, for while the

2 Almost certainly the Mahayana Buddhist belief in Maitreya or the future Buddha was influenced by the Zoroastrian teaching about the world saviour, Saoshyant. See Mary Boyce, Zoroastrians: Their Religious Beliefs and Practices (London: Routledge, 2007), 84.

3 The Dhammapada 14.190-1.

${ }^{4}$ Most Buddhists believe that there are thirty-one levels of existence, divided into five basic realms: (1) the arupa or formless realms, where a being is reborn without any body, (2) the rüpa or Brahma heavens, where a being is reborn with a body yet he is stretched out over a vast space, (3) the deva realms or the realms of the polytheistic gods, (4) the human realm, and (5) the dugatiyo realm or realm of bad destinies, such as the realm of animals, evil gods, hungry ghosts and hells. Sarah Shaw, "Appendix B," in The Jätakas, trans. by Sarah Shaw (New York: Penguin, 2006), 323-5. 


\section{NEGATIVE HAPPINESS}

Buddha felt pain, such as hunger and loneliness, which are indeed evils, he did not suffer since the pains he felt did not disturb his state of mind.

The Second Noble Truth develops the First by insisting that suffering is the result of strong craving or desperate desire. In particular, the Buddha believed that the desire for the substantial-especially the substantial self-is the cause of all suffering since such does not actually exist. In other words, because life is merely change, the desire for the permanence of the substantial, such as a substantial self (or even a substantial moral law), is the first cause of all suffering, even though, he would add, minor desires — desires which do not capture the heart or fog one's vision of the ultimate truth of reality-are to be tolerated.

The Third Noble Truth goes further than the Second, recognizing the need to eliminate strong desires and attain nirvana. Yet since this is easier said than done, people need the Fourth Noble Truth or the Eightfold Path, which are the specific steps needed in order to eliminate suffering, such as the acquisition of wisdom, the implementation of proper or virtuous conduct and the exercise of certain mental disciplines.

Consequently, while I agree with recent authorities that the Buddha should not be seen as a pessimist (since he thinks that suffering can be overcome), ${ }^{5} \mathrm{I}$ think it is equally clear that the Buddha subscribed to negative happiness or the belief that happiness is fundamentally the absence of suffering, for not only did the Buddha deny substantial reality, including a substantial self and even a substantial law of karma, but he also saw all of existence as inevitably connected with pain and thus constantly-threatening suffering-suffering which simply needs to be removed and not replaced with any substantial good, for nirvana is not a place or even, despite what some seem to suggest, a persisting substantial state, ${ }^{6}$ but rather the extinguishing of all desires, which, because this presupposes the realization that there is no substantial self (or even a substantial law of karma), ultimately leads to an escape from samsära and, for all intents and purposes, nothingness.

\section{The Negative Happiness of Epicurus}

Even though Epicurus (341-270 BC) was born on the Greek Island of Samos, he spent most of his life in Athens teaching a community of his followers in a place called "the Garden." Like most pre-Kantian ethical theories, Epicurus's ethics and theory of happiness were intimately connected with metaphysics, or, in Epicurus's case, physics.

That is, following Democritus's atomistic theory, Epicurus declared that all of existence can be understood in terms of atoms and their movement through the void. However, unlike Democritus, Epicurus was not a determinist, insisting that atoms sometimes inexplicably swerve (thus making

\footnotetext{
${ }^{5}$ John Koller, Asian Philosophies, $5^{\text {th }}$ ed. (Upper Saddle River, NJ: Pearson, 2007), 52. 2007), 40

${ }^{6}$ Joel Kupperman, Classic Asian Philosophy, $2^{\text {nd }}$ ed. (Oxford: Oxford University Press,
} 
free will possible_ or so he thought). Because Epicurus believed that all of existence is atoms moving through the void, he maintained that man's psuchê or soul must also be atomistic and hence incapable of surviving death as an enduring unique substance (in his case, a unique combination of extremely fine atoms). Moreover, Epicurus agreed with the general Greek tradition that the gods are perfectly happy, but for him this meant that they are completely free from any and all disturbances, including man's actions-both moral and immoral. Consequently, based on his physics, Epicurus insisted that there is nothing for man ultimately to fear since neither do the gods want to punish man when he dies nor is it even possible for them to do so: "The most formidable of all evils, death, is nothing to us, since, when we exist, death is not present to us, and when death is present, then we have no existence." 7 And this belief-that we have nothing ultimately to fear-is at the heart of Epicurus's ethics, particularly, his belief about the nature of happiness.

Like most of the ancient philosophers, Epicurus was a eudaimonian when it came to ethics, meaning that he believed happiness or flourishing to be the ultimate justification for ethical behaviour. However, unlike Plato, Aristotle or the Stoics, who saw virtuous action as a constituent of the happy life (i.e. virtue is to be desired for its own sake even though it is also a necessary part of happiness), Epicurus believed that virtuous action is merely a means to the end of happy living, where happy living is equivalent to pleasant living. Although this clearly makes Epicurus a hedonist, he should not be thought of as a crude subjective hedonist, who seeks out any and all pleasant kinetic experiences; rather, he should be called a negative hedonist, for he defined the deepest pleasures as katastematic or static pleasures - to wit, "freedom of the body from pain (aponia) and of the soul from suffering (ataraxia)."”

Thus, despite insisting that all pleasures are intrinsically good (and that there is no absolute morality), Epicurus maintained that by gorging oneself on kinetic pleasures, like drink, such pleasures, despite their easing natures, may still bring more pain and suffering.

For instance, in the case of drink, by over-drinking one may become physically ill or be constantly worried about saying something stupid. Indeed, despite some mild protesting, ${ }^{9}$ Epicurus might have agreed that it would be equally as well, so long as it were possible, not to feel the need for drink at all since desire itself entails lack and pain. Consequently, I think it is apparent that Epicurus was a proponent of negative happiness since not only did he deny the

7 Epicurus Letter to Menaeceus in The Lives and Opinions of Eminent Philosophers by Diogenes Laertius 10.27 .

${ }^{8}$ Ibid.

9 "He who advises the young man to live well, the old man to die well, is foolish, not only because life is desirable, but also because the art of living well and the art of dying well are one. Yet much worse is he who says that it is well not to have been born, but once born, be swift to pass through Hades' gate. If a man says this and really believes it, why does he not depart from life? Certainly the means are at hand for doing so if this really be his firm conviction." Ibid. 
intrinsic value of virtue but also understood happiness to be pleasure, which is the lack of pain and suffering.

\section{The Incompleteness of Negative Happiness}

So far I have argued that both the Buddha and Epicurus agree not only that happiness is essentially the absence of suffering but also that suffering is either absolutely (the Buddha) or intimately (Epicurus) connected with strong desire. Moreover, since the avoidance of suffering is the greatest principle for these two philosophers, both may rightly be labelled egotistical, for Epicurus explicitly declared virtue instrumental to his own pleasure and the Buddha, though he spoke of the supreme law of karma that interconnects all things, denied any substantial reality, which essentially amounts to a denial of the law of karma and hence a denial of the importance of virtue. Thus, while both philosophers emphasized an important truth-that suffering is a great evil—neither provide a completely satisfactory account of happiness, since true happiness must be a form of positive happiness, which insists upon not only the intrinsic goodness of pleasure (in this respect I agree with C. S. Lewis that "God is a hedonist at heart") ${ }^{10}$ but also at least two other factors.

First, true happiness is found in substantial, enduring things and can only be attained by a substantial, enduring self. Needless to say, this entails the belief that existence is a perfection-i.e. that it better for something to exist than not to exist. Thus, the Buddha's denial of substantial reality prevents Buddhism from being a serious contender in the quest for true happiness. And while Epicurus agreed that there is a substantial reality, for him such a reality is a myriad of atoms which swerve, collide and break apart, and ultimately point to nothing that can be identified with a unique, enduring self, whose existence is not meaningful in any deep sense: in other words, you are not you after you die and you may not even be you in this life if you are merely a collection of atoms, whose cohesion does not seem guaranteed by anything. Consequently, I think true happiness requires, among other things, something like a PlatonicChristian conception of the self.

Second, happiness requires virtue to be valuable for its own sake. Since the metaphysics of Buddhism must logically end in the denial of the absoluteness of karma, Buddhism, as I have argued, is fundamentally egotistical: while Buddhism prides itself on the interconnectedness of all things and espouses, especially in its Mahayana form, the doctrine of Bodhisattva saviours, who delay their own enlightenment for the sake of helping others, Buddhism cannot consistently maintain its emphasis on virtue while at the same time denying substantial reality, which entails the denial of the substantiality of the law of karma; in the end, if Buddhism is followed to its logical conclusion, it must admit egotism or else it must deny logic; yet if it does the latter, as in fact it often does, then all of its teachings literally become

${ }^{10}$ C. S. Lewis, The Screwtape Letters, in C. S. Lewis: Selected Books (London: HarperCollins, 1999), 794. 


\section{A. BARKMAN 77}

nonsensical, including its teachings about karma and the interconnectedness of all things. Epicureanism, of course, fares no better than Buddhism, for even though Epicurus made some half-hearted attempts to reconcile virtue with his hedonism, he was forced to admit that virtue is merely a means to the end of happiness. Because it seems fundamentally intolerable to treat people as a means to ones own happiness, I believe true happiness requires virtue to be valued for its own sake.

While I could go on and list other elements of true-positivehappiness, I believe my case has been made insofar as I wanted to show first that the Buddha and Epicurus subscribed to negative happiness and second why such a view is unacceptable.

East Asia International College, Yonsei University, South Korea

\section{References}

Boyce, Mary, Zoroastrians: Their Religious Beliefs and Practices (London: Routledge, 2007).

The Dhammapada, trans. by Glenn Wallis (New York: The Modern Library, 2007).

Epicurus, Letter to Menaeceus, in The Lives and Opinions of Eminent Philosophers, by Diogenes Laertius, trans. by C. D. Yonge (London: George Bell and Sons, 1901).

Koller, John, Asian Pbilosophies, $5^{\text {th }}$ edition (Upper Saddle River, NJ: Pearson, 2007).

Kupperman, Joel, Classic Asian Philosophy, 2 $2^{\text {nd }}$ edition (Oxford: Oxford University Press, 2007).

Lewis, C. S., "The Weight of Glory," in C. S. Lewis: Essay Collection and Other Short Pieces, edited by Lesley Walmsley (London: HarperCollins, 2000).

Shaw, Sarah, "Appendix B," in The Jätakas, trans. by Sarah Shaw (New York: Penguin, 2006). 